\title{
Cartographies as spaces of inquiry to explore of teachers' nomadic learning trajectories
}

\author{
Fernando Hernández-Hernández \\ fdohernandez@ub.edu \\ Juana M. Sancho-Gil \\ jmsancho@ub.edu \\ University of Barcelona \\ Maria Domingo-Coscollola \\ mdomingoc@uic.es \\ Universitat Internacional de Catalunya
}

\begin{abstract}
This paper is part of a research project, in which secondary teachers were invited to generate cartographies, and participate in conversations about the scenarios and where they learn and the movements they make, inside and outside school. They were also invited to think about what they valued of this performative act as a source of knowledge and experience. By generating cartographies, as a visual and textual epistemological and methodological move, we inquire those interstices, displacements, instable journeys, ways of knowing, assemblages and entanglement through which teachers explore and perform their nomadic learning paths. The main aim of this research process it is no longer about getting results but generating and putting into action concepts such as rhizome, intensity, affect, gesture, displacement, metaphor. Concepts that are helping us to think about how learning gets through teachers' movements and trajectories. Specifically, in this paper, we reflect on how nomadism localizes learning not as an outcome but as an activity staged within a processual, relational and performative ontology of becoming. In addition, we consider how all these processes affect us, as teachers and researchers.
\end{abstract}

\section{Keywords}

Post-qualitative research; secondary school teachers, nomadology; entanglement; affects; gestures. 


\section{Expanding learning boundaries}

In the last years, we have developed several research projects that placed especial emphasis in the contextual and experiential dimensions of learning. In all of them, we have explored different aspects of learning not only with primary (Hernández-Hernández, 2010) and secondary school students (Domingo-Coscollola, Sánchez-Valero, \& Sancho-Gil, 2014; Hernández-Hernández, 2017; Miño-Puigcercós \& Sancho-Gil, 2014; Sancho-Gil \& Ornellas, 2014), but also with primary, secondary and university teachers (Hernández-Hernández, Sancho-Gil, Creus, \& Montané, 2010; Sancho-Gil, 2011, 2013; Sancho-Gil \& Hernández-Hernández, 2013, 2014). These projects made evident that personal and professional knowledge cannot be separated from the biographic, cultural, social, technological, and emotional and affective experiences of the learners. In this sense, learning is embodied in an ecological process. This environmental notion of learning made us to decide the use of visual cartographies as an epistemological and methodological approach. This allows us to explore teachers' transitions and nomadic learning experiences in the scenarios inside and outside school where they learn and to think about what they value as source of knowledge and experience.

From this background, we consider learning, as

a phenomenon that involves real people who live in real, complex social contexts from which they cannot be abstracted in any meaningful way. [...] learners are contextualized. They do have a gender, a sexual orientation, a socioeconomic status, an ethnicity, a home culture; they have interests and things that bore them (Phillips, 2004, p. 10).

Because of this perspective, we assume the impossibility of restricting learning to self-contained formal learning environments. Today more than ever -in a digital al highly connected society, learning is not only a life-long, life-wide and life-deep process (Bank et al., 2007), but takes place across boundaries, times and spaces (Hernández-Hernández, 2017; Miño-Puigcercós, 2017; Sancho-Gil, 2011, 2013; Sancho-Gil \& Hernández-Hernández, 2014; Sefton-Green \& Erstad, 2017).

We also assume the difficulty of exploring a complex and slippery phenomenon such as learning through the so-called traditional measuring instruments. So, in our previous projects, we have developed professional life histories, biographical accounts, ethnographical narratives and microethnographical descriptions to explore how learning takes place. These experiences led us to the position of developing creative research methods (Fendler \& Hernández-Hernández, 2014; Fendler, Onsès, \& Hernández-Hernández, 2013; Onsès, Fendler, \& Hernández-Hernández, 2012) that also guide the research on which we focus this paper.

Thus, to investigate how people learn we took into consideration the poststructuralist ontology of nomadic thought, which is defined in terms of processes of becoming, characterized by forces, flows and fluxes that disrupt the unity of the subject (Braidotti, 2014; Deleuze \& Guattari, 2004; Jackson \& Mazzei, 2012). Therefore, a nomadic approach to teachers' learning trajectories, encourage us to be attentive to the disruptive characteristics of our inquiry process: the encounters with teachers, the uncertainties about the unknown in the research group, because it allows us to introduce provocative questions. These questions are what make our 'data' (teachers' cartographies and verbalizations, researchers' field notes, photographs and videos) shine (MacClure, 2013).

In this way, nomadology becomes an approach that considers teachers' actions and processes differently than the more humanistic concept of agency. Agency draws our attention to how teachers' capacity to act is regulated by external forces, as illustrated by the phrase "giving voice". Nomadology adopts a different approach, to consider how teachers' actions, in which they are always already engaged, affect the context in which they are embedded or introduced. This difference is captured by the shift in the perspective from teachers' voice to learning practices. Adopting a nomadic approach led us to introduce disruptive ways of thinking based on concepts 
such as "becoming, displacement, strength, assemblage, entanglement, affects, gestures...". Concepts that have circulated to name shared experiences, to expand the ways of narrating and to raise new questions about: a) What it means to generate nomadic cartographies as epistemological 'spaces', "associated with speed, flotation, and disjunctures" (Ulmer \& Koro-Ljungberg, 2015, p. 139). b) How to investigate the sources of knowledge and experience underpinning teachers' learning movements and $\mathrm{c}$ ) how to advance our understanding on the entanglement circulating among teachers professional and biographical learning experiences.

One consequence of this nomadic approach to teachers' learning movements was considering that their contributions and experiences were affecting researchers' trajectories in and out the research process. This meant that when we invited teachers to be part of the research by mapping and exploring their learning trajectories, we became part of an entanglement of relations that also affected us. When we, as part of a larger group, started thinking on the 28 cartographies created by teachers, we entered in spaces of multiple meanings. Cartographies and teachers' explanations were not taken as isolated evidences, but a rhizoanalytic opportunity for regarding our diaries, the photos we collected, the decisions for editing three videos, and the presentations shared later with the teachers, as part of these assemblages and of an immanent ethics (Cumming, 2015) that transformed what data could be. By accompanying the development of teachers' nomadic learning cartographies, we have been challenged to be involved in a process of inquiry that subverts the limits the research relationship (Atkinson, 2012). This is an event that while disturbing and transforming us modifies the traditional spaces of research at the university, leading us into the space-event of nomadic researching. This move was particularly clear when we decided to adopt cartography as the strategy for exploring and thinking on teachers' learning trajectories.

\section{Cartographies as spaces of learning entanglement}

Visual cartographies are both an epistemological tool and a rhizomatic research strategy, with a long trajectory in social sciences and education research (McKinnon, 2011; Paulston \& Liebman, 1994; Ruitenberg, 2007; Ulmer \& Koro-Ljungberg, 2015). We consider cartography as an 'inventive method' (Lury \& Wakeford, 2012) "oriented towards making difference" (Lury \& Wakeford, 2012, p. 11), because allows to link abstract concepts with their spatial dimensions (Mason, 2002; Sclater 2003). Because cartographies are also "both instruments and signifiers of spatialization... maps are models of worlds crafted through and for specific practices of intervening and particular ways of life" (Haraway, 1997, p. 135). Visual cartographies have also an extended presence on maps to give account of mythical, relational, spatial, of the known, topological frames (Biblioteca Nacional de España, 2017) and to depict physical, mental, and emotional territories, as well as for exploring social and political issues; body and life experiences, and for mapping the intangible and generating concepts.

We put into dialog the various notions and practices of cartography with Guattari's approach of 'schizoanalytic cartographies' (Guattari, 2012), considered as maps that refuse a fixed and invariant domain of subjectivity, that are rather relational configurations, which change state and status as a function of particular assemblages. In the same way that Deleuze, who considers maps as spaces of becoming, where the unconscious is 'uncovered' through "cartographic performances" (Ulmer \& Koro-Ljungberg, 2015, p. 139), Guattari contributes to on-going debates in contemporary social and educational research, regarding abstraction, affect, cartography, subjectivity, and theory. Both, Deleuze and Guattari invite us to "Make a map, not a tracing... What distinguishes the map from the tracing is that it is entirely oriented toward an experimentation in contact with the real" (Deleuze \& Guattari, 2004, p. 12).

From this review, we arrive to a notion of cartography as an 'apparatus of capture' that territorializes the new and the singular and can show assemblages, "multiplicities or aggregates of 
intensities" (Deleuze \& Guattari, 2004, p. 15). From this approach, we consider cartography as a powerful and versatile representation of personal/social learning trajectories. As a connector of experiences and knowledge of design, abstraction and translation, as well as an increaser of knowledge and appreciation toward oneself and one's learning environment (Onsès, 2014); and as "a key site for the poststructuralist critique of classical and modernist thought" (Mitchell, 2008, p. 3). In this regard, cartographies are not just an elicitation visual method but a space of entanglement, an event, in which all these substances -bodies and things, texts and situations, affects and intensities, movements and crossroads, ideas and manners of doing, etc., remain assembled, within a processual, relational and performative ontology of becoming (Atkinson, 2012). Cartographies allow asking ourselves whether mapping could help to go beyond objectivity, modern thinking, and representational logic in research.

\section{Exploring secondary school teachers' learning histories and geographies}

Building on the above rationale, we developed the research project: "How do Secondary School Teachers Learn: Educational Implications and Challenges for Addressing Social Change - APRENDO", EDU2015-70912-C2-1-R). We invited 29 teachers, 26 of them from three secondary schools placed around Barcelona, to participate in workshops for generating visual cartographies of the scenarios in which they learn inside and outside school. They were also encouraged to participate in conversations to think about how they value cartographies as source of knowledge and experience and as forms of generating understandings of their nomadic learning displacements (Braidotti, 2006, 2014), their tensions and professional learning expectations. By generating visual cartographies, not as a method, but as a way of generating knowledge, we try to inquiry the interstices, displacements, instable journeys, ways of knowing, assemblages and entanglements through which teachers perform their learning paths.

How participant teachers arrive to the project reflects the character of the nomadic research approach discussed above. Initially we conducted a pilot study with two teachers to gain first-hand experience of the process we were trying to mobilize. One of these teachers suggested taking the proposal to her school, where 10 teachers later participated. We contacted another teacher, who was also the principal in other school, and she proposed us to extend the invitation to her colleagues as well. The same thing happened with another teacher to whom we knew from a previous project, who also suggested including her schoolmates. In this way the group was configured from the unforeseen and from the creation of a network of relationships that expanded our initial purpose. At the end, 29 secondary school teachers participated in the four workshops (see table 1). Fourteen researchers participated in these research activities taking photographs, facilitating the mapping and recording the videos in which teachers related their reflection and meaning. 


\begin{tabular}{|c|c|c|c|}
\hline Schools & Number of teachers & Cartographies & Videos \\
\hline 1 & 11 & 10 & $10+1$ \\
\hline 2 & 8 & 8 & $8+1$ \\
\hline 3 & 7 & 7 & $7+1$ \\
\hline Mixed & 3 & 3 & 3 \\
\hline TOTAL & 29 & 28 & $28+3$ \\
\hline
\end{tabular}

Table 1. Participants.

Prior to the workshop, during the negations process, which took place online; teachers received a summary of the project and the voluntary participation form to be signed in advance. We also suggested them to:

- Think of what a cartography about their own learning trajectories could mean for them.

- Look for examples that could help them determine the type of cartography they wanted to make. (We enclosed exempla developed by us about our own learning experiences).

- Make a first sketch (using the format they wanted) to show the ways they learn both inside and outside their workplace.

- Search and select the materials and references they wanted to include in their cartography (photos, videos, drawings, texts, objects, documents...).

- Tell us what they needed to prepare it and bring it to the meeting.

- They were also asked to give us same basic information about their professional trajectories.

Some of the participants brought different materials with them and some of them did not. However, at the end of the workshops, all of them developed their learning cartography and gave an individual account of their processes, meanings and discovering.

The fieldwork, understood as a possibility of encounter not as a 'place' where to collect data, was carried out in two 'moments':

a) During November and December 2016, we went to three secondary schools around Barcelona, where we met with the groups of teachers. The development of the workshops proceeded as follows:

1) Research group members' presentation.

2) Teachers were asked to introduce themselves, explaining why they wanted to participate in what most of them called a "training", and advance their cartographic proposals.

3) They were asked to think of learning cartographies by considering and relating three issues previously proposed by us: a) the learning places; b) their learning moves between the inside and the outside of the institution, and c) the sense they make to the very act of learning.

4) Development of the cartographies. Teachers were provided with different resources, in addition to ones brought by them, to do the work. Our role as researchers was limited to accompanying one or two teachers and energizing -but never judging- the making of the 
cartography. Researchers observed, asked, answered questions or helped, if required by participants.

5) Once the cartography was finish, they all explained -in front of a video-camera, what they had done and why. Later the content was transcribed and related to the process of making the cartography.

6) At the end, the remaining participants (some of them left once they finished their own process) commented on the general feeling of having participated in this activity.

The workshop's activity was carefully documented through video, photos and field notes taken by the research team.

b) Six month later, between May and June 2017, we returned to the schools, to share with them our dialog what cartographies and the explanation given by teachers about them, stressing what they had allowed us to think about learning. This new round of conversations provided new insights for the teachers learning stories and ecologies. This meeting was also documented through video, photos and field notes.

During this process, we adopted "an artistic form of the social sciences, a form of radically interpretive representation" (Richardson \& St. Pierre, 2005, p. 964). Inspired on post-qualitative approaches (Jackson \& Mazzei, 2012; Lather, 2013; Lather \& St. Pierre, 2013; St. Pierre, 2011) this approach shapes a not unified movement that puts into question the very notion of research, It is no longer about getting results but generating concepts.

Instead of applying a previous method to scrutinize them, our stand on the cartographies contents was based on the acknowledgement and the potentiality of "not-knowing" (Rogoff, 2006). Thus, we were looking for a new kind of object of inquiry, "'pulled out of shape by its framings' and, equally importantly, 'framings pulled out of shape by the object'" (Lather, 2013, p. 639). To this end, the cartographies, the teachers' accounts about them and our fieldnotes were put together to produce an emerging conversation. Rather than meaning, this allowed us to open to "unexpected readings of and listening to materials in what might be termed 'fractal analysis'" (Lather, 2016, p. 127).

\section{Analysis and discussion}

Developing cartographies to map out teachers' leaning moments, places and transitions gave participants the opportunity of exploring "the sensations, intensities and textures through which" (Coleman \& Ringrose, 2014, p. 3) they experienced when learning. The multiplicity of teachers' learning worlds and the questions raised in the process not only 'caught' these realities but also made them. Considering that, we are dealing with the cartography of existential territories -which imply sensitive, cognitive, affective, aesthetic universes, and what it means to approach the cartographies of concrete processes of subjectivation (Guattari, 2000). According to Masny (2013, pp. 4-5),

Cartographies relate to mappings and mappings relate to the rhizome. Cartographies are captured through the rhizome, "movements in diverse directions instead of a single path, multiplying its own lines and establishing the plurality of unpredictable connections in the open-ended smooth space of its growth" (Semetsky, 2008, p. xv). [...] Rhizome and becoming cannot be controlled; instead, they create unpredictable lines of flight.

Thinking through these spaces, we were able to locate moments, relations and experiences of learning, but not how learning takes place. Teachers' cartographies tell stories about where, with 
whom and with what they learn, but it is unclear -unknown- what they tell us about how they learn. However, we do not consider this 'unknown' as a limitation but as a possibility for "constantly being challenged by doubts about what we don't know. This is what effective research does; it helps us to see that uncertainty and curiosity not only motivate new inquiries, but also inspires artistic impulses" (Sullivan \& Gu, 2017, p. 50).

By charting teachers' trajectories in this manner, we did not attempt to solve the question of how they 'became' learners. Instead, cartographies were used not as a representational tool but as an epistemological medium. In doing so, we unveiled what constituted their limits and invited us to consider how access these 'places' beyond pre-established research frameworks. As nomadic learning is defined in terms of processes of becoming, to think on teachers' nomadic learning movements, we put all the information we have in a chart where we were able to put in conversation each teacher's cartography (including visual evidences of their process) with the transcription of their comments and the researchers field notes and thoughts. See part of an example in figure 1.

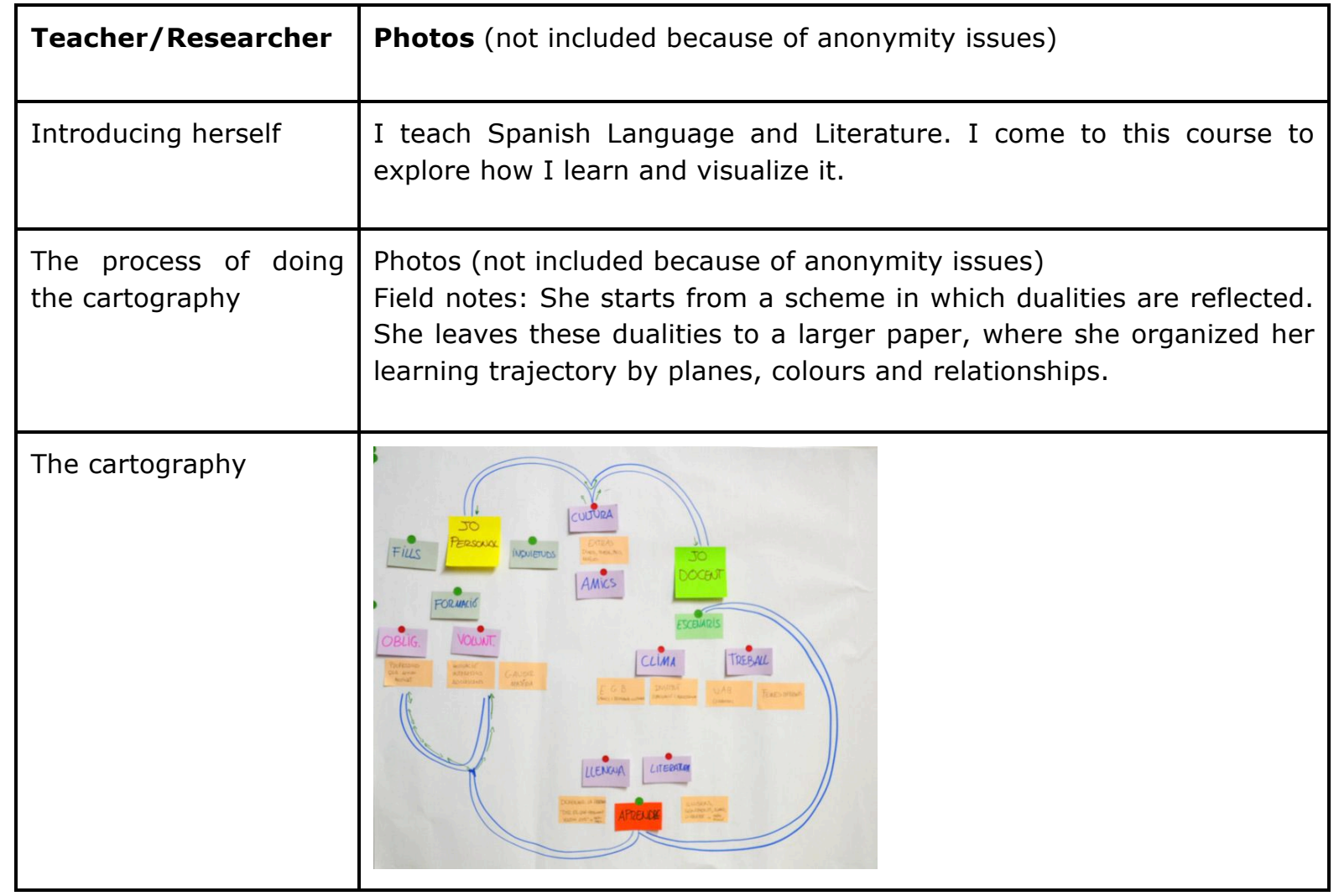




\begin{tabular}{|c|c|}
\hline $\begin{array}{l}\text { Teacher thinking on } \\
\text { her cartography }\end{array}$ & $\begin{array}{l}\text { I have divided the cartography into two blocks, the personal self and } \\
\text { the teaching self. These two blocks are or will start from the first } \\
\text { moment, in the earliest stage (...). } \\
\text { (Later) They are teachers who have motivated me for the subject and } \\
\text { made me to want to be a teacher. } \\
\text { When I was older, when I was clear about what I wanted to study, } \\
\text { what interested me, are the optional courses, chosen because I liked } \\
\text { the teacher, how he does it, for the interest of the subject itself and } \\
\text { above all to enjoy the subject and to be able to take it to my teaching } \\
\text { life (...). } \\
\text { At this point, I add to this formation my children, my children's ages, } \\
\text { how they learn and how it leads me to think, how adolescents can } \\
\text { learn. } \\
\text { In addition, I have some concerns, which I have divided into two } \\
\text { groups, culture and friends. } \\
\text { Culture goes in both directions because it unites my personal concerns } \\
\text { and my working life (...). } \\
\text { On the other hand, friends, a book shared with them, I take this to } \\
\text { class as well, and it nourishes me. } \\
\text { Participating in this experience made me think the other day, when I } \\
\text { had to fill out the questionnaire, about motivation and responsibility. } \\
\text { What forces made me to come without wanting to come and what } \\
\text { forces made me to decide to study because I like it. I thought about } \\
\text { my job in the high school, which is something you should do, not } \\
\text { because I didn't like it, but because I didn't think this activity was } \\
\text { going was be useful for something, but I was wrong. }\end{array}$ \\
\hline $\begin{array}{l}\text { What she allows us to } \\
\text { think }\end{array}$ & $\begin{array}{l}\text { (...) In short: dualities as a starting point and then building bridges } \\
\text { between inside and outside, the personal and professional, the } \\
\text { obligatory and what is derived from one's own desire. These dualities } \\
\text { reflect a permanent process of becoming, where contradictory and } \\
\text { complementary forces and fluxes reflect her nomadic learning process. } \\
\text { What images of thought (Deleuze) are reflected in her learning dual } \\
\text { movements? How the tension between 'immanence' and } \\
\text { 'transcendence' (Atkinson, Deleuze) articulate her learning paths? } \\
\text { What these displacements say about how she learns? }\end{array}$ \\
\hline
\end{tabular}

Figure 1. Chart as space to think on teachers' nomadic learning movements.

We organised all 'data' following this format. We considered each chart and the relationships among them from a nomadic approach, seeing it as a movement through the research process that works across both horizontal and vertical axes, affecting how the project advances (the questions posed along the way). As well as interacting with the different layers implicit within the research: the generation of evidences, the dialogical and rhizomatic forms of analysis, and the decisions on how to make public the research process. From this perspective, we paid attention to one the three nomadic learning spaces, defined by Jackson \& Mazzei (2009, p. 2):

\section{a. Spaces of subjectivity}

Exploring in detail the cartographies produced in the workshops we realized that they include, as a key theme, aspects linked to teachers' biographies of learning. Learning is not only a cognitive operation but also a biographic embodied experience. For instance, when Esther organizes her cartography (figure 2) on two separated levels with determination, she was allowing us to think about her desire (and long-term fight) for overcoming the difficulties found in her family 
background. Although she recognized these difficulties as a learning engine and a fundamental reason to pursuing her own cultural and professional way.

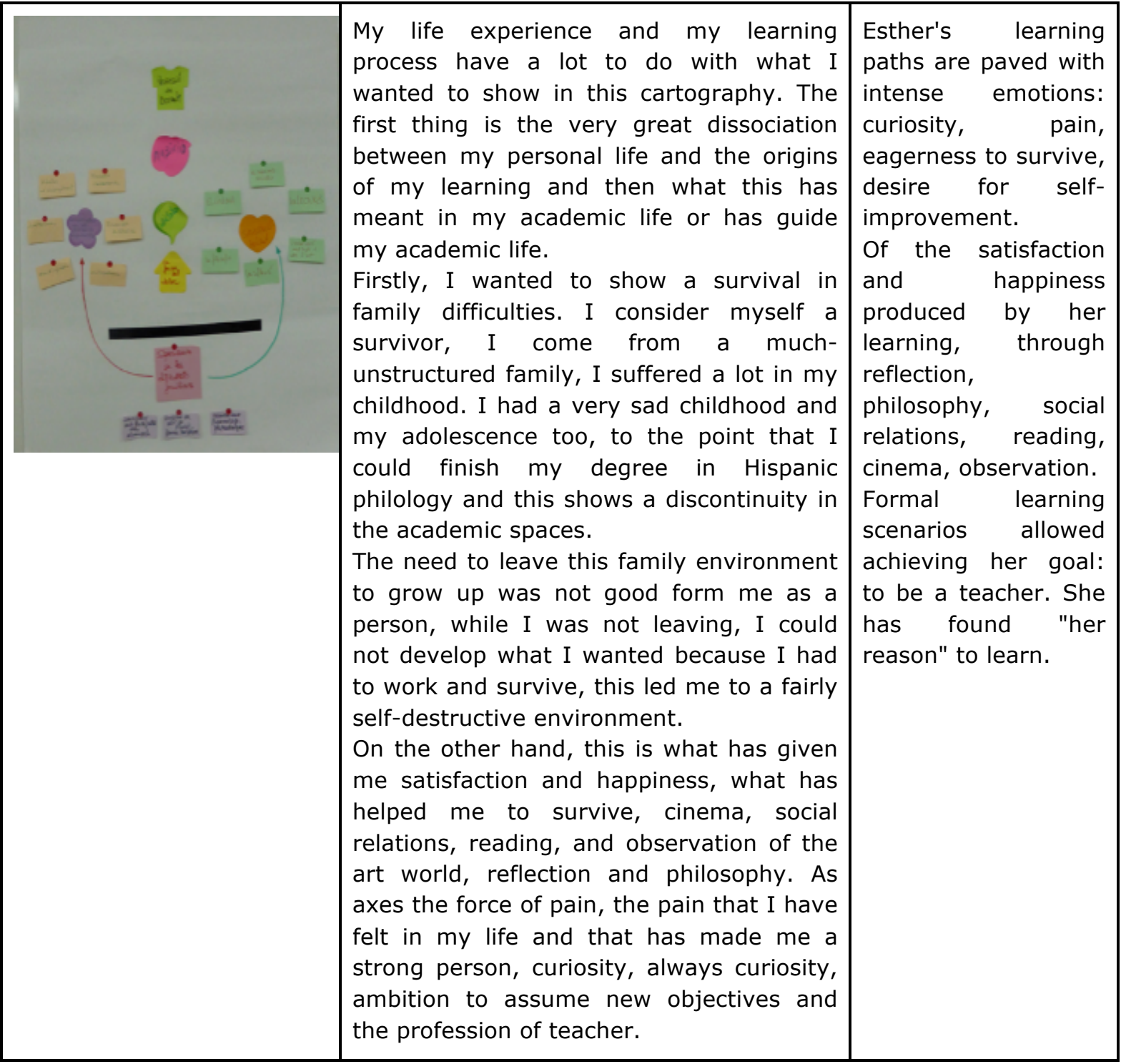

Figure 2. Esther nomadic learning movements.

Cartography is a form of visual representation organized by axes, links, key places (notions), locations, positions, distances... It is not a result but a not ending process where the producer brings their memories, experiences, desires and fantasies. Teachers' cartographies are assemblages where knowledge is produced by thinking, which elements are involved in the them and how they are interwoven.

Adriana's Olympic rings (figure 3) connected with her archived diplomas, invites us to think about the competitive and meritocratic culture in which she was born and grew up. Thus, mapping appears not only as a method of representation but also as a way to understand how the subject places and interprets learning in a network of relationships. 


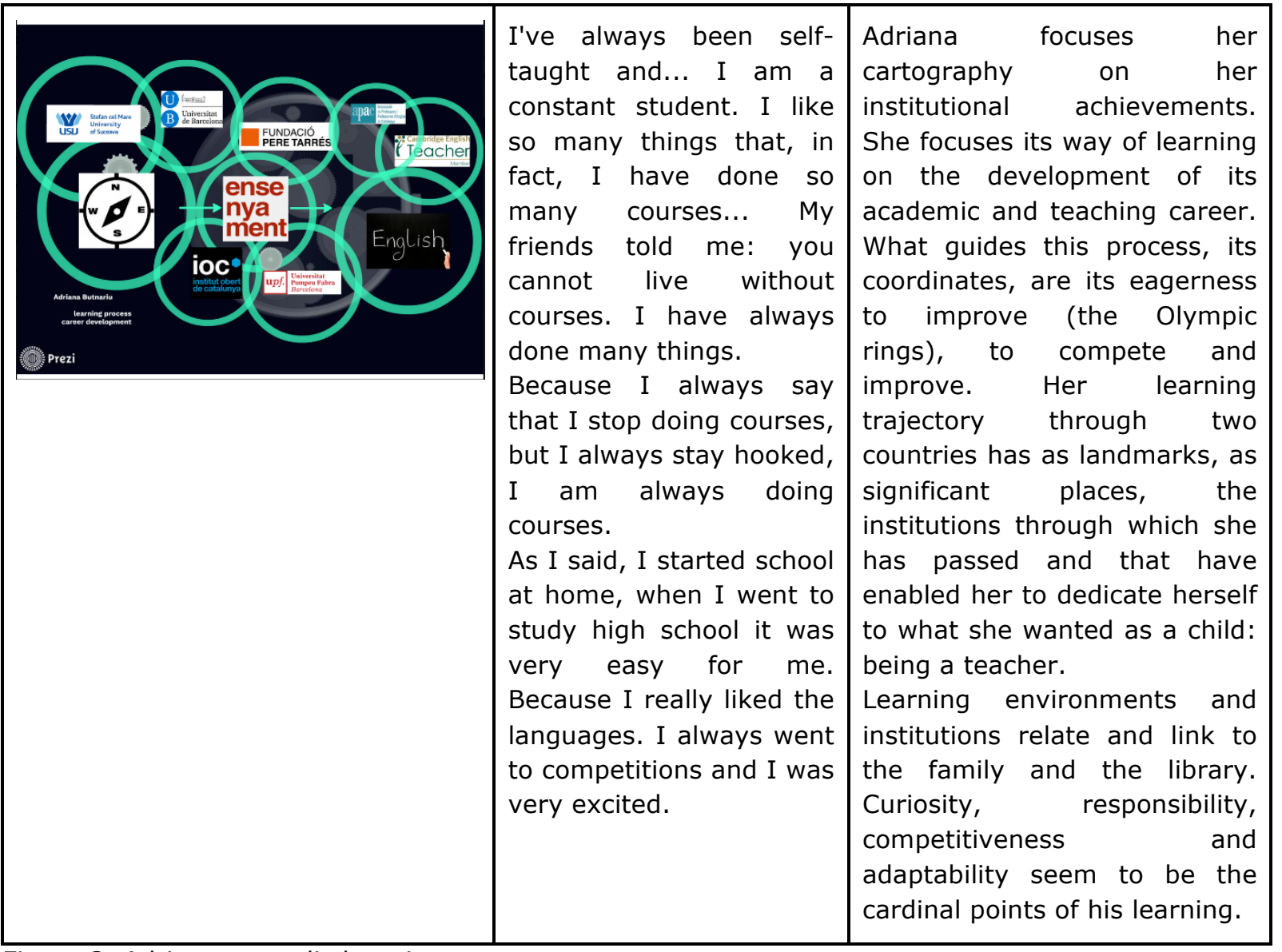

Figure 3. Adriana nomadic learning movements.

Visual cartographies, taken not as a prescriptive navigational formula, but as a fluid, dynamic process for exploration and experimenting in research, do not seek to locate or trace meanings but "to extend beyond normative forms of theorizing and representing" (Ulmer \& Koro-Ljungberg, 2015 , p. 139). This approach prevents in relation of "the use of mapping as a way of describing and interpreting any kind of learning" (Sefton-Green, 2016, p. 117). Firstly, because teachers are who represent their own trajectories, being able to escape of the colonial discourse of the maps, by using appropriation and transformation strategies. Secondly, because cartographies tell stories about where and with whom secondary school teachers learn, but it is unclear what they tell us about how they learn, because, as Biesta (2013) argues, learning is not something natural, but contextually constructed.

\section{Conclusions}

How people learn is something we cannot really know. We can locate spaces, moments and experiences of learning -hence the importance of cartographies-, but we cannot determine how learning takes place. This is because we know that it is not possible to control-to know-the learning of others. However, we frequently think that the other will reveal what we desire or how s/he thinks to learn. What teachers' cartographies allow us to understand is: (a) What happens to teachers during the elaboration process of the cartographies, and how they confronted to the new of this experience. (b) What ideas (from their learning trajectories) stood out to them, and how those ideas manifested themselves in the maps and conversations developed during our two meetings. (c) The extent to which the encounters affected teachers' individual practices, specially their understandings of students learning. (d) Anything unexpected that surprised them (or us), which seems worth sharing. 
This nomadic approach through cartographies has allowed us to also investigate with secondary school teachers and invite them to question their frames (images of thought) of what means to be teacher and learner. By inviting teachers to participate in a collaborative process to mapping out their learning trajectories, we challenged them to be involved in a process of learning that subverted the limits of the academic relationships and enabled to generate and experience an event (Atkinson, 2012). An event that at the same time disturbed them and us, transformed them and us, and modified the traditional places of investigators and investigated, the university and the secondary schools.

This was the reason why, from the very beginning, we put the stress on the preposition with, for three main reasons. Firstly, because by following an inclusive research perspective (Nind, 2014) we do not do research about people, but with people. Secondly, because working in the field of education and being profoundly interested in people's educational and learning processes and their personal and professional development, as argued by Elliott (1985), we stand for the notion of "educational research" as differentiated of "research on education". By understanding that research done in a field such as education that so deeply affects human being lives and their environment (Zembylas, 2016) we assume, as Elliott (1990, p. 4), that "the overriding purpose of educational research is to bring about worthwhile educational change"; and "research is only educational when it is directed towards realising educational values in practice". And this end can be only achieved by involving participants in the research process and considering what they perceive as the "real" problems and the conditions for them to learn. Finally, because in our conversation with the postqualitative research approach (Guttorm, Hohti, \& Paakkari, 2015; Lather, 2004, 2013; St. Pierre, 2011, 2014; St. Pierre \& Roulston, 2006) and with some of the contributions coming from the New materialism and New empiricism turn, we guide the research process considering that, as Barad (1996, p. 180) has noticed, "objectivity is literally embodied. According to agential realism, knowledge is always a view from somewhere - objective knowledge is situated knowledge".

Cartographies have been 'useful' for our research because were taken as a strategy to generate 'knowledge' and relate to the theory (concepts such as 'becoming', 'nomadic learning' 'gestures', 'rhizomatic relations', and so on), from combining different elements as drivers and articulators of an unfinished narrative. This idea of cartography is not as result but a space of thinking and making connections between teachers' nomadic learning experiences and their visual mapping process. Nomadic learning (Fendler, 2015) is used to give account of those interactions that subvert learning process, unveiling what constitutes their limits. This notion invites us to consider how access these 'places' beyond pre-established teaching and research frameworks. Some authors such as (Braidotti, 2014; Jackson \& Mazzei, 2009, 2012) have guided us to explore and signify what is outside the framework of the learning cartographies.

Most teachers involved expressed their satisfying surprise about how reflecting on their own learning using inventing methods gave them the opportunity of going beyond de "already known", of thinking differently about students' learning and exploring expression tools to fostering reflection beyond words.

From the researchers' side we have been able to think around the following questions:

- How to reinvent research methods (Lury \& Wakeford, 2012) to deal with the fluidity, multiplicity and vagueness (Law, 2004) of learning experiences.

- How to understand the multiplicity of teachers' learning worlds and the questions raised by methods that not only 'catch' these realities but also make them.

- How to map those relations where researchers are always involved.

In this research, visual cartographies are not only visual and textual forms of expression, but also a process of collaboration and generation of concepts that go beyond the visual representation. For teachers and researchers, this means, "in a sense putting [ourselves] at risk, becoming 
unrecognised within the normalising frameworks that govern [our] practice" (Atkinson, 2011, p. 5). Finally, our stand on the cartographies assumes the acknowledgement that they are not a prescriptive navigational formula, but a fluid, dynamic process for exploring and experimenting in research.

\section{Funding}

Spanish Ministry of Economy, Industry and Competitiveness [EDU2015-70912-C2-1-R].

\section{Acknowledgment}

ESBRINA - Contemporary Subjectivities, Visualities and Educational Environments (2017SGR 1248): http://esbrina.eu.

REUNI+D -University Network for Educational Research and Innovation. MINECO [EDU2015-68718REDT: http://reunid.eu.

\section{References}

Atkinson, D. (2011). Art, equality and learning: Pedagogies against the state. Rotterdam: Sense.

Atkinson, D. (2012). Contemporary Art in Education: The New, Emancipation and Truth. The International Journal of Art \& Design Education, 31(1), 5-18. doi: 10.1111/j.1476-8070.2012.01724.x

Banks, J., Au, K., Ball, A. F., Bell, P., Gordon, E. W., Gutiérrez, K. D., ... Zhou, M. (2007). Learning in and out of school in diverse environments. life long, life-wide, life-deep. Seattle: University of Washington-The LIFE Center for Multicultural Education.

Barad, K. (1996). Meeting the Universe Halfway. Realism and Social Constructivism without Contradiction. In Feminism, Science, and the Philosophy of Science (pp.161-194). Dordrecht/Boston/London: Kluwer Academic Publishers.

Biblioteca Nacional de España (2017). Cartografías de lo desconocido (Carthographies of the unknown). Madrid: Biblioteca Nacional de España.

Biesta, G. J. J. (2013). The Beautiful Risk of Education. Boulder, CO: Paradigm.

Braidotti, R. (2006). Transpositions. On Nomadic Ethics. Cambridge, UK: Polity Press.

Braidotti, R. (2014). Writing as a nomadic subject. Comparative Critical Studies, 11(2-3), 163-184. doi: $10.3366 /$ ccs.2014.0122

Coleman, R., \& Ringrose, J. (2014). Deleuze and research methodologies. Edinburgh: Edinburgh University Press.

Cumming, T. (2015). Challenges of 'thinking differently' with rhizoanalytic approaches: a reflexive account. International Journal of Research \& Method in Education, 38(2), 137-148. doi: $10.1080 / 1743727 X .2014 .896892$

Deleuze, G., \& Guattari, F. (2004). A thousand plateaus: Capitalism and schizophrenia. Translated by B. Massumi. London: Continuum.

Domingo-Coscollola, M., Sánchez-Valero, J. A., \& Sancho_Gil, J. M. (2014). Researching on and with Young People: Collaborating and Educating. Comunicar, 42(1), 157-164. doi: 10.3916/C42-2014-15

Elliott, J. (1985). Educational action research. In J. Nisbet, J. Megarry \& S. Nisbet (Eds.), Research, Policy and Practice, World Yearbook of Education (pp. 231-25). London: Kogan Page. 
Elliott, J. (1990). Educational research in crisis: performance indicators and the decline in excellence. British Educational Research Journal, 16(1), 3-18. doi: 10.1080/0141192900160101

Fendler, R. (2015). Navigating the eventful space of learning: Mobilities, nomadism and other tactical maneuvers. (Unpublished doctoral dissertation). University of Barcelona, Barcelona.

Fendler, R., \& Hernández-Hernández, F. (2014). Using arts-based research strategies to document learning in a course on arts-based research. In R. Marín, J. Roldán \& X. Molinet (Eds.), Foundations, criteria, contexts in arts based research and artistic research (pp. 157-168). Granada: Universidad de Granada.

Fendler, R., Onsès, J., \& Hernández-Hernández, F. (2013). Becoming arts-based researchers: A journey through the experience of silence in the university classroom. International Journal of Educations through Art, 9(2), 257-263. doi: 10.1386/eta.9.2.257_7

Guattari, F. (2000). Cartografías Esquizoanalíticas. Buenos Aires: Manantial.

Guattari, F. (2012). Schizoanalytic Cartographies. London: Bloomsbury.

Guttorm, H., Hohti, R., \& Paakkari, A. (2015). "Do the next thing". An interview with Elizabeth Adams St. Pierre on post-qualitative methodology. Reconceptualizing Educational Research Methodology, 6(1), 15-22. doi: $10.7577 /$ rerm. 1421

Haraway, D. (1997). Modest_Witness@Second_Millenium FemaleMan_Meets_OncoMouse. Feminism And Technoscience. London and New York: Routledge.

Hernández-Hernández, F. (Ed.). (2010). Aprender a ser en la escuela primaria. Barcelona: Octaedro.

Hernández-Hernández, F. (Ed.). (2017). iY luego dicen que la escuela pública no funciona! Investigar con los jóvenes sobre cómo transitan y aprenden dentro y fuera de los centros de Secundaria. Barcelona: Octaedro.

Hernández-Hernández, F., Sancho-Gil, J. M., Creus, A., \& Montané, S. (2010). Becoming university scholars: Inside professional autoethnographies. Journal of Research Practice, 6(1). Retrieved from http://jrp.icaap.org/index.php/jrp/article/view/204/188

Jackson, A. Y., \& Mazzei, L. (2009). Voice in Qualitative Inquiry: Challenging Conventional, interpretive, and Critical Conceptions in Qualitative Research. London \& New York: Routledge.

Jackson, A. Y., \& Mazzei, L. (2012). Thinking with theory in qualitative research: Viewing data across multiple perspectives. NewYork: Routledge.

Lather, P. (2004). This is your father's paradigm: Governmental intrusion and the case of qualitative research in education. Qualitative Inquiry, 10,15-34. doi: 10.1177/1077800403256154

Lather, P. (2013). Methodology-21: what do we do in the afterward?, International Journal of Qualitative Studies in Education, 26(6), 634-645. doi: 10.1080/09518398.2013.788753

Lather, P. (2016). Top Ten + List: (Re)Thinking Ontology in (Post)Qualitative Research. Cultural Studies Critical Methodologies, 16(2), 125-131. doi: 10.1177/1532708616634734

Lather, P., \& St. Pierre, E. A. (2013). Post-qualitative research. International Journal of Qualitative Studies in Education, 26(6), 629-633.

Law, J. (2004). After Method: Mess in Social Science Research. London \& New York: Routledge.

Lury, C., \& Wakeford, N. (2012). Inventive Methods: The Happening of the Social (Culture, Economy, and the Social). New York: Routledge.

MacClure, M. (2013). Classification or wonder? Coding as an analytic practice in qualitative research. In R. Coleman \& J. Ringrose (Eds.), Deleuze and Research methodologies (pp. 164-183). Edinburgh: Edinburgh University Press. 
Masny, D. (2013). Cartographies of Becoming in Education. Theory and Practice. In D. Masny (Ed.), Cartographies of Becoming in Education: A Deleuze-Guattari Perspective (pp. 3-16). Rotterdam \& Taipei: Sense Publishers.

Mason, J. (2002). Qualitative interviewing: asking, listening and interpreting. In T. May (Ed.), Qualitative research in action (pp. 225-242). London: Sage.

McKinnon, I. (2011). Expanding Cartographic Practices in the Social Sciences. In E. Margolis \& L. Pauwels (Eds.), The SAGE Handbook of Visual Research Methods (pp. 452-473). London: SAGE.

Miño-Puigcercós, R. (2017). Trajectòries d'aprenentatge a través de contextos Dos estudis de cas sobre els trànsits dels joves entre els dins i el fora de l'escola. Unpublished PhD. University of Barcelona.

Miño-Puigcercós, R., \& Sancho-Gil, J. M. (2015). Learning by using digital media in and out of school. Seminar.net. International Journal of Media, Technology \& Lifelong Learning, 11(1).

Mitchell, P. (2008). Cartographic strategies of postmodernity: The figure of the map in contemporary theory and fiction. New York: Routledge.

Nind, M. (2014). What in inclusive research? London \& New York: Bloomsbury Publishing.

Onsès, J. (2014, May). Subjective Cartographies: Mapping the network of neighbourhood relationships in the neighbourhood of Poble Sec. Paper presented at the Conference Mapping Culture: Communities, Sites and Stories, Coimbra (Portugal).

Onsès, J., Fendler, R., \& Hernández-Hernández, F. (2012). Una investigación a/r/tográfica sobre la experiencia del silencio en las clases de la universidad. inVISIBILIDADES. Revista Ibero-Americana de Pesquisa em Educação, Cultura e Artes, 3, 29-40.

Paulston, R. G., \& Liebman, M. (1994). An Invitation to Postmodern Social Cartography. Comparative Education Review, 38(2), 215-232. doi: 10.1086/447242

Phillips, D. C. (2014). Research in the Hard Sciences, and in Very Hard "Softer" Domains. Educational Researcher, 43(1), 9-11. doi: 10.3102/0013189X13520293

Richardson, L., \& St. Pierre, E. A. (2005). Writing: A method of inquiry. In N. K. Denzin \& Y. S. Lincolns (Eds.), The SAGE handbook of qualitative research (3rd ed., 959-978). Thousand Oaks, CA: Sage.

Rogoff, I. (2006). Academy as Potentiality. Zehar, 60-61, 4-9.

Ruitenberg, C. (2007). Here be dragons: Exploring Cartography in Educational Theory and Research. Complicity: An International Journal of Complexity and Education, 4(1), 7-24.

Sancho-Gil, J. M. (Ed.). (2011). Con voz propia. Los cambios sociales y profesionales desde la experiencia de los docentes. Barcelona: Octaedro.

Sancho-Gil, J. M. (Ed.). (2013). Trayectorias docentes e investigadoras en la universidad. 24 historias de vida profesional. Barcelona: Dipòsit digital de la Universitat de Barcelona. Retrieved from http://diposit.ub.edu/dspace/handle/2445/44965

Sancho-Gil, J. M., \& Hernández-Hernández, F. (2013). Developing Autobiographical Accounts as a Starting Point in Research. European Educational Research Journal, 12(3), 342-353. doi: 10.2304/eerj.2013.12.3.342

Sancho-Gil, J. M., \& Hernández-Hernández, F. (Eds.). (2014). Maestros al vaivén. Aprender a ser docente en el mundo actual. Barcelona: Ediciones Octaedro.

Sancho-Gil, J. M., \& Ornellas, A. (2014). Growing and learning in multidimensional surroundings. Connecting inside and outside school experiences. REM-Research on Education and Media, 6(2), 47-58.

Sclater, D. (2003). The arts and narrative research. Qualitative Inquiry, 9(4), 621-625. 
Sefton-Green, J. (2016). Representing learning lives: what does it mean to map learning journeys? International Journal of Educational Research, 84, 111-118. doi: 10.1016/j.ijer.2016.05.003

Sefton-Green, J., \& Erstad, O. (2017). Researching 'learning lives' a new agenda for learning, media and technology. Learning, Media \& Technology, 42(2), 246-250. doi: 10.1080/17439884.2016.1170034

St. Pierre, E. A. (2011). Post Qualitative Research. The Critique and Coming After. In N. Denzin \& Y. S. Lincoln (Eds.), The SAGE Handbook of Qualitative Research. (pp. 611-625). Thousand Oaks, CA: SAGE.

St. Pierre, E. A. (2014). A Brief and Personal History of Post Qualitative Research Toward "Post Inquiry". Journal of Curriculum Theorizing, 30(2), 2-19.

St. Pierre, E. A., \& Roulston, K. (2006). The state of qualitative inquiry: a contested science International Journal of Qualitative Studies in Education, 19(6), 673-684. doi: 10.1080/09518390600975644

Sullivan, G., \& Gu, M. (2017). The possibilities of Research-The promise of Practice. Art Education, 70(2), 4957. doi: $10.1080 / 00043125.2017 .1274203$

Ulmer, J. B., \& Koro-Ljungberg, M. (2015). Writing Visually Through (Methodological) Events and Cartography. Qualitative Inquiry, 2(2), 138-152. doi: 10.1177/1077800414542706

Zembylas, M. (2016). Affect Theory and Judith Butler: Methodological Implications for Educational Research. In M. Zembylas \& P. A. Schutz (Eds.), Methodological Advances in Research on Emotion and Education (pp. 203-214). Springer International Publishing. 